\title{
Ocupar, reivindicar, participar: sobre o repertório de ação do movimento de moradia de São Paulo
}

\begin{tabular}{c}
\hline \hline Luciana Tatagiba \\
Departamento de Ciência Política \\
Universidade Estadual de Campinas \\
Stella Zagatto Paterniani \\
Mestranda em Antropologia Social \\
Universidade Estadual de Campinas \\
Thiago Aparecido Trindade \\
Doutorando em Ciências Sociais \\
Universidade Estadual de Campinas \\
\hline \hline
\end{tabular}

Resumo: Este artigo tem como objetivo discutir três eixos comuns que compõem o repertório de ação do movimento de moradia da cidade de São Paulo: as ocupações de imóveis ociosos, a participação institucional (especialmente no Conselho Municipal de Habitação) e o direito a morar no centro da cidade. Buscamos recuperar um pouco da história dessas práticas e rotinas, e apresentamos a heterogeneidade dos argumentos, que as sustentam e as questionam. Apresentamos o movimento que se sustenta heterogêneo e plural, cujos militantes têm no horizonte a luta por moradia digna. $\mathrm{O}$ artigo tem como base um survey aplicado no $11^{\circ}$ Encontro Estadual de Moradia Popular, organizado pela União dos Movimentos de Moradia (UMM), ocorrido em São Paulo, no ano de 2009.

Palavras-chave: movimento social; direito à cidade; participação; ocupações; Conselho de Habitação

Abstract: This article aims to discuss three common lines that make up the action repertoire of the housing movement of the city of São Paulo: squattings, participation in institucional spheres, (specially the Municipal Housing Council) and the right to the city. We intended to recover part of the history of these practices and routines, and here we present the heterogeneity of the arguments that support and question them. Therefore, we present the housing movement as heterogeneous and plural, whose militants struggle for dignified housing. The article is based on a survey, applied in the $11^{\text {th }}$ State Meeting of Popular Housing, organized by the Union of the Housing Movement, which happenned in São Paulo, in 2009.

Keywords: social movement; right to the city; participation; squatting; Housing Council

OPINIÃO PÚBLICA, Campinas, vol. 18, no 2, novembro, 2012, p. 399 - 426 


\section{Apresentação}

O movimento de moradia é hoje um dos principais movimentos populares da cidade de São Paulo. É consenso na bibliografia que suas origens podem ser encontradas nas lutas de moradores de cortiços contra as altas taxas de água, luz e IPTU, os abusos dos intermediários, os despejos sem aviso prévio e pela regulamentação de loteamentos no final dos anos 1970 e início dos anos 1980 (cf. Gohn, 1991; Kowarick, 1988). De lá para cá, o drama habitacional na cidade só fez aumentar. De 1980 a 2000 , o número de domicílios na Região Metropolitana de São Paulo saltou de cerca de três milhões para cinco milhões - e desses, estima-se que mais de um milhão encontre-se em favelas (MARQUES e TORRES, 2002). Segundo levantamento de 2009, feito pela Secretaria Municipal de Habitação, existem 127.084 cortiços espalhados pela cidade. Dados oficiais indicam ainda a dinâmica perversa que orienta a ocupação da cidade: dados preliminares do Censo 2010 mostram que há cerca de 290 mil imóveis ociosos na cidade de São Paulo, enquanto, de acordo com as informações da Secretaria Municipal de Habitação, cerca de 130 mil famílias não têm onde morar.

É em referência a esse cenário de negação de um direito básico de cidadania que o movimento de moradia erigiu-se como ator coletivo sob a chave do direito à moradia digna. A afirmação desse direito reconhece uma carência coletiva e, ao mesmo tempo, denuncia e aciona um campo de conflitos atualmente muito evidente nas disputas envolvendo o direito à moradia no centro da cidade. De um lado, propostas como a da Nova Luz ${ }^{2}$, encampada pela Prefeitura de São Paulo e setores da sociedade e do mercado convergente com a gentrification ${ }^{3}$ do centro da cidade; reintegrações de posse, muitas vezes violentas, em ocupações de imóveis ociosos; expulsão dos moradores de rua do centro da cidade ${ }^{4}$. De outro lado, propostas de ocupação dos imóveis vazios do centro com Habitação de Interesse Social (HIS) e luta por maior participação da população nos espaços de decisão e debate sobre a política habitacional paulistana. Trata-se de um conflito que ao mesmo tempo incorpora e vai além da questão da moradia como acesso à unidade residencial - articulando referências ético-políticas que permitem afirmar a existência de diferentes projetos políticos (DAGNINO, OLVERA e PANFICHI, 2006) que disputam os recursos e 0 acesso à cidade.

O movimento de moradia é, como dissemos, um ator central nessas disputas, demonstrando uma

\footnotetext{
${ }^{1}$ As pesquisas que subsidiam este artigo foram desenvolvidas no âmbito do Núcleo de Pesquisa em Participação, Movimentos Sociais e Ação Coletiva (NEPAC.Unicamp), que, além dos autores, congrega outros alunos e pesquisadores, sob a coordenação da Profa Luciana Tatagiba. O NEPAC-Unicamp está registrado no diretório de grupos e núcleos de pesquisa do CNPq. Os resultados aqui apresentados são parte de uma agenda mais ampla de pesquisa no âmbito do projeto internacional e comparado "Dinâmica e atores latino-americanos de participação", envolvendo Brasil, França e México, com a coordenação de Camille Goirand (IEP/Lillie), com financiamento da AIRD /França. O CNPq também financiou essa pesquisa.

2 Uma iniciativa da Prefeitura de São Paulo, que prevê a revitalização da área do polígono formado pelas avenidas Ipiranga, São João, Duque de Caxias, rua Mauá e avenida Cásper Líbero - a chamada cracolândia. Na prática, tal projeto de revitalização implica na valorização de prédios históricos com vias a intensificar o setor de serviços e o mercado imobiliário e turístico na região. É possível acessar o projeto no site da Prefeitura de São Paulo em: <http://www.novaluzsp.com.br/projeto.asp>. Acesso em: 06 jan. 2011.

${ }^{3}$ Os processos de gentrification conjugam intervenção no patrimônio, requalificação dos usos da cidade e melhorias na infra. estrutura urbana no centro. Através da manipulação do conceito de tradição, transmuta o patrimônio cultural em mercadoria com as complexidades que essa transfiguração sugere. Para uma profunda discussão sobre o conceito, ver Leite, 2007.

${ }^{4}$ Como aponta o Dossiê de Denúncia do Fórum Centro Vivo, 2006. Disponível em:

<http://dossie.centrovivo.org/imagem/dossie_cd.pdf>. Acesso em 08 jan. 2011.
} 
TATAGIBA, L.; PATERNIANI, S. Z.; TRINDADE, T. A. Ocupar, reivindicar, participar...

grande capacidade de mobilização e pressão. Um dos motivos que explica a força desse movimento está na capacidade que ele tem demonstrado de aprender com a experiência da interação conflitiva com o Estado, diversificando suas estratégias de ação e combinando-as de forma criativa a partir das oportunidades e constrangimentos impostos pela conjuntura.

O movimento de moradia desenvolveu ao longo da experiência de interação conflitiva com o Estado um conjunto de práticas e rotinas que conformaram um repertório de ação no qual se destacam como estratégias principais, embora não exclusivas: 1) a ocupação de prédios e terrenos públicos; 2) a participação em espaços institucionais; 3) a luta por moradia no centro e 4) a construção por mutirão autogestionário. Essas estratégias foram experimentadas ao longo do tempo a partir de uma tradição que, historicamente, combinou a ação disruptiva com uma intensa prática de negociação com os agentes públicos, principalmente nas periferias urbanas (CARDOSO, 1983; 1987). Em torno dessas práticas e valores o movimento de moradia se estrutura, se define e se apresenta à sociedade enquanto um ator coletivo, ator este que, a despeito de sua heterogeneidade interna, caracteriza-se pelo compartilhamento de um determinado projeto político.

Nas nossas pesquisas, o conceito de repertório de ação coletiva tem sido bastante útil para compreender como o movimento tem buscado responder ao desafio da coordenação da ação coletiva em contextos e conjunturas variados.

O conceito de repertório de ação coletiva pode ser definido como um "campo limitado de rotinas que são aprendidas, compartilhadas e executadas através de um processo relativamente deliberado de escolha" (TILLY 1995a, p. 26). Nos trabalhos de Tilly (1995a; 1995b; 2006) e Tarrow (2009) encontramos os principais esforços de definição conceitual e os mais sugestivos usos do conceito para análises empíricas, embora ainda com um nível considerável de imprecisão. As ideias por trás do conceito remetem a um interessante jogo entre tradição e inovação na conformação da ação coletiva. Como afirma Tilly, na ação coletiva, "os atores fazem o que sabem fazer". O conceito remete a uma valorização da memória e do saber da ação coletiva. É pela experiência da luta que os campos em conflito conformam suas práticas e discursos. Um repertório, nesse sentido, não é algo que um ator possui, e do qual dispõe de forma estratégica; um repertório pertence ao conjunto dos atores em conflito, uma vez que incorpora a memória das lutas anteriores e suas inovações (TILLY, 1995a). Por essa chave, vemos como os aspectos estratégico e instrumental, práticas e valores mostram-se inelutavelmente vinculados na conformação da ação coletiva: "repertórios são criações culturais aprendidas, mas eles não se originam de abstrações filosóficas ou como resultado da propaganda política; eles emergem da luta" (TILLY, 1995a, p. 26).

Mas, se a tradição conforma o campo das ações possíveis, ao fazerem o que sabem fazer e o que aprenderam a fazer os atores também estabelecem um diálogo ativo e criativo com o passado, realizando inovações. Ou seja, uma dimensão central da noção de repertório é que ao mesmo tempo em que ele é aprendido do passado, é também constantemente transformado pelos atores no presente. A importância do contexto e da conjuntura é a segunda ideia por trás do conceito de repertório. Segundo Dilley (1999), “(...) contextos são conjuntos de conexões construídas como relevantes para alguém, para alguma coisa ou para um problema particular e este processo produz uma explicação, um sentido, uma 
interpretação para o objeto conectado. O contexto, ou enquadramento, também produz uma disjunção entre o objeto de interesse e suas imediações, por um lado, e aquelas características que são excluídas e vistas como irrelevantes, por outro." (DILLEY, 1999, p.2, livre tradução nossa). Pode-se então considerar o contexto não como elementos externos ao nosso objeto de pesquisa, mas como as relações estabelecidas e reconfiguradas do objeto com esses elementos circundantes. Do balanço entre dimensões estruturais e conjunturais resulta um ambiente político mais ou menos favorável à ação coletiva dos movimentos sociais. No contexto enquanto relação, os movimentos produzirão respostas que, em parte, expressam sua capacidade de agência e, em outra parte, os constrangimentos do cenário no qual atuam. Nesse sentido, o conceito de repertório nos ajuda a endossar uma análise relacional e evitar, de um lado, os riscos de uma análise voluntarista - presente na ideia de que os atores escolhem suas estratégias de ação, como se não houvesse limites culturais e conjunturais colocados para essas escolhas - e, de outro lado, os riscos de uma análise determinista - na qual os atores sempre repetirão os caminhos conhecidos, sem capacidade de reposta ativa e criativa diante dos constrangimentos estruturais.

$\mathrm{O}$ artigo tem como objetivo abordar três das quatro estratégias que compõem o repertório de ação do movimento de moradia de São Paulo - as ocupações, a participação institucional e a disputa pelo centro ${ }^{5}$, recuperando parte da história dessas práticas e rotinas e problematizando o nível de adesão dos militantes às ideias que as sustentam ${ }^{6}$. 0 artigo tem como base um survey aplicado no $11^{\circ}$ Encontro Estadual de Moradia Popular, organizado pela União dos Movimentos de Moradia (UMM), ocorrido em São Paulo de 15 a 17 de maio de 2009 no Sindicato dos Bancários. O Encontro tinha como objetivos eleger a Coordenação Executiva da UMM e definir as suas linhas de atuação para os próximos dois anos ${ }^{7}$. O locus de realização do survey já conforma, de saída, um recorte na rede do movimento de moradia, ao privilegiar organizações vinculadas à UMM. O questionário foi composto por 23 perguntas fechadas e 19 perguntas abertas, as quais foram submetidas a posterior codificação, e semiabertas. As tabelas apresentada ao longo do artigo são compostas por categorias definidas por nós após leitura e análise das respostas dadas pelos militantes, no esforço de buscar convergências e divergências. Foram aplicados 147 questionários, dos quais 108 (73\%) entre os militantes delegados; 34 (23\%), entre os militantes não delegados; e 5 (4\%) para os convidados $^{8}$. No planejamento da amostra, buscamos ser fiéis à composição da UMM, seguindo suas quatro grandes divisões: São Paulo, ABCD, Macro Sudeste e Interior. Assim, das 147 pessoas entrevistadas, 78,2\% eram da capital; 2,8\% do ABCD; 3,4\% da Macro Sudeste; e $15,6 \%$ do Interior $^{9}$.

\footnotetext{
5 Por questão de espaço, os mutirões não foram analisados neste artigo.

6 Cabe esclarecer que estes eixos de "entrada no campo" foram definidos no decorrer do esforço coletivo de pesquisa desenvolvida pelo NEPAC. Ou seja, eles não resultam de uma definição a priori, mas sim uma tentativa a posteriori de sistematizar nossos "achados de campo".

${ }^{7}$ Conforme consta no site da organização:

<http://www.unmp.org.br/index.php?option=com_content\&view=article\&id=47\&ltemid=58>. Acesso em: 18 abr. 2010.

8 Os delegados são aqueles escolhidos por suas organizações locais para representá-las no Encontro Estadual; os militantes não delegados são os participantes do movimento que não possuem poder de voto nas plenárias; convidados são aqueles que mantêm vínculos com as organizações específicas de movimentos sociais, mas que não participam dela diretamente. Membros de ONGs, do Conselho de Habitação, funcionários da Prefeitura e da Cohab são exemplos de convidados.

${ }^{9}$ Para a realização do survey, contamos com a assessoria técnico-científica dos pesquisadores do Centro de Estudos de Opinião Pública (CESOP/ Unicamp). Agradecemos especialmente à Prof ${ }^{a}$ Dr $^{\text {a }}$ Rachel Meneguello e aos técnicos Rosilene Sydney Gelape e Samuel Silva Pereira, pela disposição, solicitude e orientação durante o processo de elaboração do questionário e posterior
} 
TATAGIBA, L.; PATERNIANI, S. Z.; TRINDADE, T. A. Ocupar, reivindicar, participar...

Os resultados apontam, por um lado, para uma significativa adesão dos militantes aos valores e práticas que conformam o repertório de ação do movimento. Por outro lado, os dados expressam também a heterogeneidade interna do movimento e a diversidade dos sentidos da participação e das (re)configurações da experiência militante. A partir dessa dupla chave, buscamos evidenciar o trabalho de conformação discursiva que subjaz à construção das ações do movimento, visando à legitimação e ao reconhecimento das suas práticas junto a sua base, aliados, contendores e público em geral. Destacamos a ambiguidade e a polissemia de sentidos (POLETTA, 1998) que conforma a ação coletiva em torno da moradia digna, na qual discursos e ações com forte componente conflitivo e disruptivo coexistem com a defesa de valores dominantes.

O artigo está dividido em três partes, para além dessa introdução e da conclusão. A primeira traz uma breve contextualização do movimento de moradia a partir das suas principais organizações, com destaque para a União dos Movimentos de Moradia (UMM). Na sequência, analisamos os dados obtidos a partir das perguntas fechadas do nosso questionário, apresentando um perfil, ainda que plural, do militante do movimento, com ênfase sobre os padrões de recrutamento e os sentidos da participação no movimento. Por fim, discutimos a história e o nível de adesão dos militantes no que se às estratégia de ocupação, participação institucional e a luta pelo centro - três dos quatro eixos que identificamos como centrais.

\section{O movimento de moradia da cidade de São Paulo e a UMM ${ }^{10}$}

O movimento de moradia da cidade de São Paulo é uma rede composta por indivíduos e organizações que ao mesmo tempo em que mantêm seus objetivos, agendas e formas específicas de atuação, buscam coordenar suas ações para atuar coletivamente em prol da moradia digna. Este movimento, antes fragmentado e disperso em razão das próprias demandas que caracterizam sua origem, possui, atualmente, uma estrutura organizacional forte e hierarquizada, capaz de articular diversas organizações em diferentes níveis e escalas geográficas (local, regional, nacional e mesmo internacional).

O primeiro esforço de estruturação organizacional do movimento resultou na criação da Unificação das Lutas de Cortiços (ULC), constituída juridicamente em 1991, e que permanece até hoje. A ULC tinha como meta principal aglutinar os movimentos envolvidos na luta pela melhoria das condições de habitação coletiva na área central e na região leste/sudeste, bem como "denunciar as condições de vida nos cortiços e encaminhar as reivindicações dos seus moradores para o poder público" (NEUHOLD, 2009, p. 44). Paralelamente à conformação da ULC, surge em 1987, enquanto comunidade política e sob forte influência das Pastorais da Moradia e das Comunidades Eclesiais de Base, a União dos Movimentos de Moradia (UMM) (CAVALCANTI, 2006, p. 62).

codificação dos dados. Também agradecemos à Profa Evelina Dagnino pelas contribuições para a elaboração do questionário. As entrevistas foram realizadas pelos membros do NEPAC após treinamento. O trabalho de codificação dos dados ficou a cargo de Stella Paterniani, sob a coordenação da Prof ${ }^{a}$ Luciana Tatagiba. Os resultados preliminares estão disponíveis em Paterniani, 2010 (relatório de pesquisa).

${ }^{10}$ Este item foi escrito com a colaboração de Larissa Meneses, também membro do NEPAC, a quem especialmente agradecemos. 
OPINIÃO PÚBLICA, Campinas, vol. 18, no 2, novembro, 2012, p. $399-426$

A UMM iniciou como uma organização municipal que tinha como objetivo agregar, conforme as lutas se intensificavam, aqueles que participavam das ocupações generalizadas no período; em 1992, porém, adquiriu caráter estadual, e começou a desenvolver vínculos com a Central dos Movimentos Populares (CMP), de caráter nacional. Como organização articuladora no nível estadual, a UMM organizou uma espécie de 'federação' de entidades e movimentos locais e regionais aglutinados em torno de lideranças políticas fortes e segmentadas espacialmente. Dentro de cada macrorregião, existem grupos menores, denominados "grupos de origem", cujo referencial geográfico mínimo são os bairros em que atuam os coletivos menores: são as unidades elementares de toda a estrutura, e fortemente autorreferenciadas pelos próprios militantes ${ }^{11}$.

Atualmente, a UMM organiza-se internamente em movimentos e secretarias. As organizações de movimentos dividem-se entre Região Metropolitana - a qual, por sua vez, divide-se em Capital, ABCD e Macro-Sudeste - e Interior - com as Macros Jundiaí, Campinas, Baixada e Sorocaba. Só na capital, a União congrega quinze organizações menores - as quais, por sua vez, aglutinam grupos e associações locais, que somam, segundo dados oficiais, mais de vinte mil famílias cadastradas. Há coordenações de níveis estadual e regional, bem como secretarias que discutem temas transversais - como formação política, mulheres, LGBTT, juventude etc. A UMM integra redes nacionais (União Nacional Por Moradia Popular, Fórum da Reforma Urbana) e internacionais de luta pela moradia (Habitat International Coalition América Latina, Secretaria Latinoamericana Vivienda Popular, Rede Mulher e Habitat).

Além da UMM e das organizações de movimentos que a compõem, nos anos 2000, outra organização articuladora se consolida: a Frente de Luta por Moradia (FLM), que surge oficialmente em 2004 e congrega organizações de movimentos "dissidentes" de organizações que compõem a UMM. Encontramos, na bibliografia sobre o tema, considerações sobre as cisões e segmentações no movimento de moradia (Benolt, 2000; CavalCANTI, 2006; NeuHold, 2009). Um dos aspectos mais comumente mobilizados - tanto pelos atores como pela bibliografia de referência - para explicar essas disputas remete à divergência em relação às formas de atuação. Especificamente, a utilização (ou não) da estratégia de ocupar prédios e terrenos vazios como forma de luta e as vantagens e limites do diálogo com o Estado.

À primeira vista antagonistas - principalmente por discordarem quanto às formas de ação que o movimento deve privilegiar -, UMM e FLM não se reduzem à falsa dicotomia entre "privilegiar inserção institucional" e "privilegiar ocupação", como veremos a seguir. Há descontinuidades e contradições nos posicionamentos de militantes que pertencem a uma mesma organização, bem como há convergência de posicionamentos entre indivíduos pertencentes a diferentes organizações. 0 que nossas pesquisas evidenciam é que as disputas internas não têm impedido o movimento de agir e apresentar-se como um ator coletivo, que compartilha uma pauta política comum. Vide o caso das recentes ocupações no centro de São Paulo (início de novembro de 2011), em que a própria mídia noticiou o fato como uma das ações

\footnotetext{
11 Propomos utilizar o conceito de "organização de movimento social", cunhado originalmente por Zald e Ash (1966), para nos referir a coletividades específicas, como o Movimento de Moradia do Centro (MMC). Entendemos por organizações articuladoras as organizações que congregam outras organizações (como a UMM), as quais, por sua vez, são geralmente compostas por associações de bairro ou organizações que se referenciam na unidade mínima de sociabilidade (que é, com frequência, o bairro).
} 
TATAGIBA, L.; PATERNIANI, S. Z.; TRINDADE, T. A. Ocupar, reivindicar, participar...

mais articuladas dos "Sem-Teto" na capital paulista desde a emergência do movimento na cena pública.

Resta claro, então, que não consideramos o movimento de moradia da cidade de São Paulo como um sujeito monolítico; antes, pensamos o movimento como o encontro entre atores em ações promovidas e performadas numa coletividade mais ou menos coesa. Por mais diversos que sejam os motivos que levam alguém a participar do movimento de moradia, a se declarar militante desse movimento e a se envolver com sua realidade; e por mais ramificadas que sejam as relações entre as pessoas que transitam entre o movimento de moradia - e compõem outros movimentos sociais, partidos, espaços governamentais e institucionais, universidades, ONGs, defensorias e delegacias -, o movimento de moradia é por essas mesmas pessoas constantemente reconfigurado e suficientemente maleável para ser reivindicado por elas à luz daquilo que, para cada uma delas, faz sentido como espaço de participação e luta.

\section{Configurações militantes: perfil, recrutamento e participação}

Mais da metade dos entrevistados é do sexo feminino (57,8\%), confirmando estudos que apontam a forte participação das mulheres em ações coletivas, principalmente em torno de demandas por políticas sociais. Um dado interessante é que as mulheres são maioria não apenas na base do movimento, mas também ocupam posições de liderança em várias organizações. Quanto à idade, há uma predominância dos adultos, na faixa dos 40 aos 59 anos (Tabela 1).

Tabela 1

Idade dos militantes entrevistados

\begin{tabular}{|l|c|c|}
\hline Categorias & N & $\%$ \\
\hline Menor de 18 anos & 02 & 1,4 \\
\hline $18 \cdot 29$ anos & 21 & 14,3 \\
\hline $30 \cdot 39$ anos & 28 & 19,0 \\
\hline 40.59 anos & 75 & 51,0 \\
\hline 60 e mais & 20 & 13,6 \\
\hline NR & 01 & 0,7 \\
\hline Total & 147 & 100,0 \\
\hline
\end{tabular}

Fonte: Pesquisa Movimento de Moradia, 2009.

É preciso considerar que o Encontro congregava lideranças locais, os delegados, que são pessoas que, no geral, possuem uma trajetória mais longa no movimento, o que, talvez, explique a baixa participação dos jovens $(15,7 \% \text { da amostra })^{12}$. No que se refere aos indicadores socioeconômicos, $34,7 \%$ possuem renda familiar de até dois salários mínimos e $43,5 \%$ de dois a quatro salários mínimos. Assim, $78,2 \%$ dos entrevistados possuem renda familiar de até quatro salários mínimos. A maioria $(60,5 \%)$ dos entrevistados está empregada e, desses, $42 \%$ trabalham com carteira assinada.

Quanto à educação formal (Tabela 2), 42,8\% não possuem o ensino fundamental completo, 32\%

\footnotetext{
12 De qualquer forma, nesse Encontro, decidiu-se pela criação de mais uma secretaria na UMM, a Secretaria da Juventude, visando fortalecer a militância da juventude.
} 
OPINIÃO PÚBLICA, Campinas, vol. 18, n², novembro, 2012, p. $399-426$

concluíram o ensino médio, $10 \%$ concluíram o ensino superior e $12 \%$ estão na faculdade.

Tabela 2

Escolaridade dos militantes entrevistados

\begin{tabular}{|l|l|l|}
\hline \multicolumn{1}{|c|}{ Categorias } & N & $\%$ \\
\hline Ensino médio incompleto & 63 & 42,8 \\
\hline Ensino médio completo & 48 & 32,7 \\
\hline Ensino superior em curso & 18 & 12,2 \\
\hline Ensino superior concluído & 16 & 10,9 \\
\hline Analfabeto & 1 & 0,7 \\
\hline NR & 1 & 0,7 \\
\hline Total & 147 & 100,0 \\
\hline
\end{tabular}

Fonte: Pesquisa Movimento de Moradia, 2009.

Apenas 20 entrevistados (13\%) afirmam não possuir religião. Como vemos na Tabela 3, dos que possuem religião, $57 \%$ se declaram católicos. A Igreja Católica continua forte no campo da moradia, principalmente por meio de suas pastorais, mas já é significativa a presença dos não católicos, em especial os que professam a religião protestante.

Tabela 3

Vinculação religiosa dos militantes entrevistados

\begin{tabular}{|l|c|c|}
\hline \multicolumn{1}{|c|}{ Categorias } & N & \% \\
\hline Católico & 73 & 57,5 \\
\hline Evangélico & 33 & 26,0 \\
\hline Outra & 21 & 16,5 \\
\hline Total & 127 & 100,0 \\
\hline
\end{tabular}

Fonte: Pesquisa Movimento de Moradia, 2009.

Além de forte vinculação com a religião católica, o participante do movimento de moradia possui vínculos expressivos com o Partido dos Trabalhadores. Quando perguntamos se os entrevistados eram próximos a algum partido político, 72,\% responderam que sim. Desses, 91,6\% afirmaram simpatia pelo PT, e 2,8\% pelo PSDB. Outros partidos foram citados, como PCB, PP, PV, PSOL, PCdoB, PTB, todos com menos de $1 \%$ de frequência. Destaca-se ainda o tempo de militância no PT: $41 \%$ dizem ser filiados ou simpatizantes há mais de 20 anos. Esse resultado confirma nossas expectativas pela histórica relação entre a UMM e o PT desde a fundação de ambos. Ao longo de toda a sua história, essas organizações compartilharam seus militantes a partir de um - no geral - produtivo trânsito entre as fronteiras do partido e do movimento, o qual permitiu a circulação de informações, projetos e recursos diversos. Nos trabalhos de campo, temos visto um intenso trânsito de militantes do movimento para os diretórios zonais do PT, assim como para os gabinetes dos parlamentares ligados ao Partido. A partidarização do movimento, aqui compreendida sob a chave da múltipla filiação dos seus militantes ${ }^{13}$, ficou evidente também quando perguntamos aos entrevistados quais eram os principais antagonistas do movimento: para $31 \%$, os inimigos do movimento eram os partidos e governos alinhados à direita, DEM e PSDB

${ }^{13}$ Sobre o tema da múltipla filiação e seus impactos sobre os movimentos, remetemos ao interessante estudo de Mische (2008). 
TATAGIBA, L.; PATERNIANI, S. Z.; TRINDADE, T. A. Ocupar, reivindicar, participar...

principalmente ${ }^{14}$.

Quanto ao tempo de participação no movimento, os dados da Tabela 4 mostram um interessante equilíbrio entre pessoas com longa trajetória de militância e pessoas que acabaram de chegar.

Tabela 4

Tempo de participação no Movimento de Moradia

\begin{tabular}{|l|c|c|}
\hline \multicolumn{1}{|c|}{ Categorias } & N & \% \\
\hline Até 1 ano & 19 & 12,9 \\
\hline De 2 a 4 anos & 29 & 19,7 \\
\hline De 5 a 10 anos & 47 & 32,0 \\
\hline De 11 a 19 anos & 21 & 14,3 \\
\hline Mais de 20 anos & 30 & 20,4 \\
\hline NR & 1 & 0,7 \\
\hline Total & 147 & 100,0 \\
\hline
\end{tabular}

Fonte: Pesquisa Movimento de Moradia, 2009.

A Tabela 4 indica também a capacidade atual de recrutamento do movimento: $32 \%$ dos entrevistados iniciaram sua trajetória de militância na moradia nos últimos 4 anos. A primeira década de 2000 foi de forte ingresso no movimento: mais de 64\% dos entrevistados se incorporaram ao Movimento de Moradia a partir de $2001^{15}$. Quanto aos motivos para a participação no MOM (Tabela 5), a resposta espontânea de $56,4 \%$ dos entrevistados reporta ao bem imediatamente demandado: a conquista da moradia. Contudo, fazem questão de qualificá-la: moradia digna. Como já mencionado, a moradia digna contrapõe-se à realidade vivenciada por muitos: a moradia precária em cortiços, favelas, a moradia incerta que depende do Bolsa Aluguel ou da ajuda de parentes e/ou amigos, moradia "sem papel passado", que espera regularização. A ideia da dignidade remete também a um cenário que pode integrar às demandas por moradia outras demandas, como uma moradia que permita acesso a outros bens e serviços essenciais, por exemplo, emprego, transporte, saúde e educação. A "moradia digna" é um referente simbólico que qualifica a luta e a conquista e diz sobre a natureza de um engajamento que, se está voltado a uma reivindicação concreta e urgente - de gozo individual -, tem potencialidade para ativar outros sentidos e motivações. Das respostas contempladas nessa categoria "para conquistar moradia digna", 27\% fizeram questão de apontar para as mudanças sofridas após o ingresso no movimento, como resultado do aprendizado da participação. Essas respostas mencionavam o processo de alguém que entrou no movimento de moradia para conseguir uma casa e que, independentemente de ter ou não a conquistado, ampliou a percepção da demanda como coletiva, a partir de experiências que fortaleceram a relação entre a identidade individual e a participação no movimento, e permaneceu no

\footnotetext{
${ }^{14}$ Em recente estudo, Tatagiba e Blikstad (2011) exploraram esse tema na análise da participação do movimento de moradia na eleição dos representantes populares para o Conselho Municipal de Habitação.

${ }^{15}$ Embora este dado demonstre a capacidade do movimento e de suas lideranças em recrutar novos militantes, ele também reflete a (difícil) situação econômica enfrentada pelas classes trabalhadoras urbanas nas últimas décadas. Em que pese a melhora do desempenho da economia brasileira nos anos recentes em comparação às décadas de 1980 e 1990 , é inegável que as condições de vida nos grandes centros urbanos em relação à moradia ainda estão longe do ideal para um enorme contingente da população.
} 
OPINIÃO PÚBLICA, Campinas, vol. 18, n², novembro, 2012, p. $399-426$

movimento agora com o princípio de continuar a luta por moradia não só para si, mas "para os companheiros que também necessitam".

Tabela 5

Motivos para participação no Movimento de Moradia

\begin{tabular}{|l|c|c|}
\hline \multicolumn{1}{|c|}{ Respostas } & N & \% \\
\hline Para conquistar moradia digna & 83 & 56,4 \\
\hline $\begin{array}{l}\text { O desejo, anterior ao ingresso no movimento, de lutar coletivamente por melhores } \\
\text { condições de vida }\end{array}$ & 23 & 15,6 \\
\hline Por influência de outras pessoas e da participação em outros espaços & 16 & 10,9 \\
\hline Por identificação com as causas do movimento & 09 & 6,1 \\
\hline Outros & 16 & 10,9 \\
\hline Total & 147 & 100,0 \\
\hline Fonte: Pesquisa Movimento de Moradia, 2009. &
\end{tabular}

Nas demais categorias, vemos esses outros sentidos ativados. Para 15,6\% dos entrevistados, o motivo para participar do movimento foi o desejo de lutar coletivamente por melhores condições de vida. As respostas contidas nessa categoria expressam a meta, anterior à entrada no movimento, de lutar por maior igualdade social - por vezes expressa a partir de uma experiência (pessoal ou compartilhada) de injustiça, e legitimada pela constitucionalidade dos direitos sociais e pela percepção do caráter coletivo da carência. Estão então contemplados nessa categoria os militantes que ansiavam /utare vislumbraram, no movimento de moradia, uma oportunidade. Com frequência menor, é citada a influência de outras pessoas e da participação em outros espaços (10,9\%), e uma menção geral a identificação com as causas do movimento $(6,1 \%)$.

Além das motivações, buscamos saber quais as estruturas que favoreceram o contato com o movimento, ligando aspirações e desejos a uma forma concreta de engajamento coletivo. As respostas confirmam a importância das redes pessoais no recrutamento de novos militantes. Mais da metade dos entrevistados $(53,1 \%$ ) afirma ter sabido da existência do movimento através de amigos e parentes. Entretanto, é bom atentarmos que as pessoas circulam e assumem diferentes cargos institucionais: o amigo pode, muitas vezes, ser da associação de moradores ou da igreja, por exemplo. Mas o vínculo mais forte, relembrado e mobilizado pelos entrevistados, é o da amizade. Reforçando o que diz a bibliografia sobre o tema, ter amigos em um movimento aumenta a chance de uma pessoa se engajar nesse tipo de ação coletiva, criando a disposição para participar (DIANI e MCADAM, 2003).

Perguntamos também aos entrevistados como avaliam a sua participação no movimento e quais as consequências dessa participação sobre suas vidas (Tabela 6): 
TATAGIBA, L.; PATERNIANI, S. Z.; TRINDADE, T. A. Ocupar, reivindicar, participar...

Tabela 6

Percepção dos ganhos para a vida pessoal com a militância no Movimento de Moradia

\begin{tabular}{|l|c|c|}
\hline \multicolumn{1}{|c|}{ Respostas } & N & \% \\
\hline $\begin{array}{l}\text { Consciência política, maior conhecimento dos direitos, maior sensibilidade para } \\
\text { questões sociais e da política habitacional }\end{array}$ & 73 & 49,7 \\
\hline Crescimento pessoal, autoconfiança, autoestima, esperança. & 28 & 19,1 \\
\hline Ampliação dos espaços de convivência social & 10 & 6,8 \\
\hline Benefícios materiais (conquista da moradia e outros) & 10 & 6,8 \\
\hline Não trouxe nada & 10 & 6,8 \\
\hline Outros & 8 & 5,4 \\
\hline NS/NR & 8 & 5,4 \\
\hline Total & 147 & 100 \\
\hline
\end{tabular}

Fonte: Pesquisa Movimento de Moradia, 2009.

A resposta mais frequente menciona a formação política resultante do processo de participação no movimento: consciência política, conhecimento dos direitos, nova visão de mundo, cidadania. Nessa categoria, destacam-se frases como "aprendi que precisa lutar", "que precisa se organizar", "que a ação é necessária", "que a gente tem que se unir para conseguir um objetivo"; além de referências ao resgate da identidade como resultado da participação no movimento, pela experiência de sentir-se parte de uma coletividade. Não é só o conhecimento dos direitos e a consciência política que são citados como impactantes: também o conhecimento das questões e processos técnicos referentes à política habitacional (como a legislação e os processos legais de regularização de terrenos, por exemplo). A segunda categoria mais frequente de respostas $(19,1 \%)$ destaca a recuperação da autoestima, o crescimento pessoal, a autoconfiança e a maior capacidade de comunicação ("perdi o medo de falar"). Já os benefícios materiais foram menos frequentes - citados por apenas dez indivíduos. Este dado nos revela que a percepção dos entrevistados sobre os benefícios de sua participação no movimento não se restringem à conquista material - neste caso, a moradia. A ênfase dos entrevistados em conquistas que dizem respeito ao aprofundamento da cidadania, do pensar sobre o estar-na-cidade (consciência política, conhecimento de direitos), e em impactos em sua subjetividade, como (recuperação da autoestima, esperança) é um dado de pesquisa extremamente rico para ser explorado no sentido de aperfeiçoar o complexo debate teórico sobre os resultados e as finalidades da mobilização coletiva (CRESS e SNOW, 2000; GIUGNI, 1998).

\section{Os repertórios de ação do movimento de moradia}

\section{As ocupações: direito de propriedade, direito à moradia digna}

As decisões quanto às formas de ação envolvem muitos dilemas, como nos lembra Tarrow, (1997). As ocupações, como ações disruptivas de alto risco, tendem a aprofundar a coesão interna à organização do grupo, mas, ao mesmo tempo, podem enfraquecer a solidariedade externa ao 
OPINIÃO PÚBLICA, Campinas, vol. 18, n², novembro, 2012, p. $399-426$

movimento, tanto pela incerteza que escancaram - paira sempre a possibilidade de uso da violência quanto pelo questionamento que lançam sobre princípios socialmente valorizados, como a propriedade privada. É preciso também considerar que a abertura de novos espaços de participação, como os conselhos e fóruns, ao mesmo tempo em que faculta novas arenas e chances para o encaminhamento de demandas, acaba por deslegitimar ações consideradas "radicais" e colocar os movimentos na defensiva. Como sublinhado por Miagusko (2008, p.11), são consideradas legítimas apenas aquelas ações reivindicatórias que operam e se encaminham por dentro das esferas institucionais do Estado, ao passo em que aqueles que optam por atuar fora dessa esfera - promovendo ocupações, por exemplo - sofrem um processo de criminalização e desqualificação de suas ações diante da opinião pública. As regras do jogo estão definidas a priori e não há espaço para negociação e diálogo com seus "transgressores". 0 artigo publicado recentemente no jornal O Estado de São Paulo pelo atual prefeito da capital paulista, Gilberto Kassab, não poderia ser mais coerente com essa análise. Referindo-se aos imóveis vazios ocupados pelo movimento de moradia no início de novembro, o prefeito faz a seguinte ponderação: "As invasões são incompreensíveis, forçam a quebra de um diálogo que não interromperemos. Como não abriremos mão de medidas judiciais de reintegração de posse dos prédios, para retomar os projetos acordados com os próprios invasores" (KASSAB, 2011).

Foi através do ato de ocupar prédios e imóveis ociosos, no início do ano de 1997, que o movimento de moradia apareceu de forma mais incisiva no debate público sobre o centro de São Paulo. Como nos recorda Neuhold (2009, p. 51), a estratégia de ocupação de imóveis e/ou terrenos vazios, tanto no campo como na cidade, não era um fenômeno inédito em termos de ação política, mas a grande novidade nas ocupações iniciadas a partir de 1997 foi o seu caráter amplamente coordenado e articulado, construído a partir de uma pauta pré-estabelecida de reivindicações "e com uma rede de apoiadores que produziram ou consolidaram 'discursos' sobre o direito da população de baixa renda habitar uma área consolidada da cidade" ${ }^{16}$. Contudo, o desgaste sofrido pelos militantes que viviam em ocupações e os resultados efetivos dessa forma particular de ação - as ocupações costumavam terminar com despejos violentos -, foram decisivos na reavaliação da ocupação como estratégia de luta, no final da década de 1990 e início de 2000. Um caso foi emblemático: a ocupação de um edifício na Rua Abolição, que se deu entre 1999 e 2005, divisor de águas entre a ênfase a) nas ocupações para pressionar ou b) ocupações para morar. Na ocupação da Abolição, o tráfico de drogas tomou o controle e uma pessoa foi morta num conflito entre traficantes. O Movimento de Moradia do Centro (MMC) e o Fórum de Cortiços (ambos filiados à UMM) divergiam com a ULC no que dizia respeito ao caráter das ocupações: não mais compartilhavam da ocupação para morar como estratégia de luta, mas propunham manter ocupações breves, de edifícios públicos e privados ociosos no centro de São Paulo. Essa mudança no caráter das ocupações - e os diferentes posicionamentos das lideranças em relação ao uso dessa estratégia - foi um dos fatores que favoreceu a dissensão no interior do movimento, como já mencionamos.

\footnotetext{
16 Entre 1997 e 2007, de acordo com Neuhold (2009, p. 70), foram realizadas 72 ocupações de imóveis ociosos na área central de São Paulo, sendo 33 em imóveis públicos e 31 em imóveis privados, além de 8 ocupações em que não foi possível identificar o proprietário do imóvel (setor público ou pessoa física e/ou jurídica privada).
} 
TATAGIBA, L.; PATERNIANI, S. Z.; TRINDADE, T. A. Ocupar, reivindicar, participar...

Oferecemos uma lista de atividades realizadas pelo movimento (marchas, ocupações, bloqueios de rua, participação no $\mathrm{CMH}$, mutirão, etc.) e pedimos que o entrevistado informasse em quais dessas atividades ele nunca participaria. Mais da metade dos entrevistados $(53,1 \%)$ afirmam que, em tese, participaria de qualquer uma das atividades promovidas pelo movimento; enquanto 38\% afirmam que nunca participariam de ocupações e bloqueios de rua. Quando indagados sobre os motivos pelos quais não participariam, 34,4\% afirmaram temer a violência policial e 27,9\% justificaram a opinião enfatizando a importância do diálogo, da negociação e da busca de meios legais para a solução de conflitos.

Em seguida, perguntamos diretamente aos entrevistados sua posição sobre as ocupações (Tabela 7):

Tabela 7

Opinião dos militantes sobre as ocupações ("festas")

\begin{tabular}{|l|c|c|}
\hline \multicolumn{1}{|c|}{ Respostas } & & $\%$ \\
\hline Sou favorável & 5 & 57,8 \\
\hline Sou contrário & 7 & 32,0 \\
\hline Outros & 6 & 4,1 \\
\hline NS/NR & 9 & 6,1 \\
\hline Total & 47 & 100,0 \\
\hline
\end{tabular}

Como vemos, as ocupações são uma estratégia de luta apoiada por 57,8\% dos entrevistados. Exploramos também os motivos que justificam a adesão. Entre os favoráveis ao uso dessa estratégia, 49,4\% justificaram sua posição afirmando que a ocupação é instrumento político legítimo e eficaz para pressionar o governo a garantir os direitos dos cidadãos e chamar atenção de outros setores da sociedade para os problemas concernentes à moradia. "São necessárias para abrir negociação, como as greves nas fábricas", foi uma das respostas que ouvimos. Já para 27,3\% dos entrevistados favoráveis à ocupação, o argumento principal foi de natureza pragmática: há na cidade de São Paulo muitos imóveis ociosos e, ao mesmo tempo, pessoas precisando de moradia. É importante lembrar que o fato de existirem prédios vazios no centro da cidade não significa que todos os segmentos da sociedade concordem que eles sejam ocupados por pessoas de baixa renda. A estratégia política contida na afirmação de que "a ocupação é um instrumento de luta legítimo porque existem imóveis ociosos" reside precisamente na combinação de um argumento relativamente pragmático - há espaço vazio que deve ser preenchido; a denúncia da ociosidade do imóvel tem apelo geral - com uma concepção política específica da realidade, isto é, com um projeto político alinhado à defesa da moradia digna para as classes populares no centro da cidade - quem deve preencher esse imóvel vazio: pessoas que moram na rua, ou que moram em condições indignas. É uma construção argumentativa moralmente difícil de ser contestada. Essa combinação argumentativa resulta, inclusive, da habilidade do movimento de moradia 
OPINIÃO PÚBLICA, Campinas, vol. 18, n², novembro, 2012, p. $399-426$

em construir simbólica e discursivamente a luta pelo direito à cidade.

Outros 30,6\% dos entrevistados deram respostas que apresentavam condicionantes para o apoio. O primeiro tipo de condição era que a ocupação se amparasse em circunstâncias legais, que estivesse de acordo com a ordem jurídica e burocrática. Não temos clareza do que seriam exatamente essas circunstâncias, mas algumas nos foram indicadas, como: o imóvel estar ocioso de acordo com os termos das leis que determinam imóveis ociosos; ou a condição do imóvel ser público, e não privado - ainda que ocioso, o imóvel privado é propriedade alheia, e ocupá-la seria, no mínimo, desrespeitoso e não condizente, portanto, com indivíduos que lutam por reconhecimento como cidadãos. O segundo tipo de condição dizia respeito à organização: os entrevistados se diziam favoráveis às ocupações desde que fossem bem organizadas anteriormente, durante o período de ocupação e no pós-ocupação - quer o imóvel fosse transformado em habitação de interesse social, quer os militantes fossem despejados, com força policial cumprindo reintegração de posse. Uma forte proposta de organização é a existência de atividades de geração de renda na ocupação.

Ambas as condições podem transformar-se em argumentos para deslegitimar ou argumentar contra a ocupação. Quando a primeira condição - a legalidade das ocupações - se engessa, constrói-se a categoria "Contrário às ocupações porque desrespeitam a propriedade privada" (25,5\%); e, da segunda cujo principal elemento é o medo da repressão policial -, advêm os "Contrários [às ocupações] porque são violentas e perigosas" (34\%) (conforme Tabela 8). O mesmo ocorre com o terceiro tipo de condição: quando as negociações não evoluem, ou seja, "a favor como último recurso...". Essa resposta parece partir da ponderação de que a ocupação é instrumento radical, mas legitima-se politicamente quando o diálogo com as instituições governamentais não acontece, ou, antes, quando a comunidade não se identifica com a política governamental, como observamos na seguinte fala de um delegado: "Eu tenho questionado ocupação. Para mim, é ato extremo. Só deve ter quando todas as portas se fecham. Ocupação é fundo do poço, só faz (sic) quando não tem outra alternativa" (quest. 58) ${ }^{17}$. A distribuição dos argumentos dos 47 entrevistados posicionados contrariamente às ocupações está na Tabela 8:

\footnotetext{
17 As citações de "quest. [número]" são referências aos questionários por nós aplicados no survey supracitado.
} 
TATAGIBA, L.; PATERNIANI, S. Z.; TRINDADE, T. A. Ocupar, reivindicar, participar...

Tabela 8

Motivo pelo qual é contra a ocupação

\begin{tabular}{|l|c|c|}
\hline \multicolumn{1}{|c|}{ Respostas } & N & $\%$ \\
\hline São violentas e perigosas & 16 & 34,0 \\
\hline Desrespeitam a propriedade privada & 12 & 25,5 \\
\hline Coloca a opinião pública contra o movimento & 8 & 17,0 \\
\hline É uma ação radical. Deve-se buscar o diálogo & 2 & 4,3 \\
\hline NS/NR & 09 & 19,1 \\
\hline Total & 47 & 100,0 \\
\hline
\end{tabular}

Fonte: Pesquisa Movimento de Moradia, 2009.

O medo da repressão policial é um argumento mobilizado por $34 \%$ dos que se posicionaram contra as ocupações. A criminalização dos movimentos sociais, ao lado da criminalização da pobreza, tem sido uma prática recorrente das administrações municipais que se sucederam desde 2005 (PSDB, DEM e PSD) da cidade de São Paulo, com reintegrações de posse violentas e repressões truculentas não só ao movimento de moradia, mas também ao movimento dos sem-teto, ao movimento estudantil e ao movimento dos moradores de rua.

A defesa da propriedade privada, com 25,5\%, é um dos argumentos de peso, que aparece quase sempre ao lado de um argumento meritocrático para conquista da casa. Pudemos observar a questão da propriedade privada e do mérito de se conquistar a sua própria casa como pano de fundo para muitas respostas, quer a favor, quer contra as ocupações. Uma resposta favorável à ocupação parece justamente dialogar com os contrários que se valem do argumento da propriedade e do mérito: "[Ocupar é importante] para eles [o governo (sic)] terem mais ciência da quantidade [de pessoas sem moradia digna] e que o povo precisa de moradia. Ocupamos quando tem prédio abandonado. Vamos lá mostrar que tem gente precisando (...), não é pra ganhar imóvel gratuito" (grifo nosso, quest. 49). Uma resposta contrária, para ilustrar, que parece embutir os mesmos pressuspostos: "Não sou a favor [das ocupações] porque não é meu. Sou a favor de conseguir a minha casa" (quest. 46). Este é um posicionamento interessante e que merece, no mínimo, uma reflexão. A rigor, o argumento "sou contrário à ocupação porque o imóvel tem dono" confere ao direito de propriedade precedência sobre qualquer outro, além de demonstrar que a propriedade privada é concebida como um princípio inviolável mesmo por aqueles que não a detêm. Trata-se, portanto, de um direito amplamente aceito e legitimado na sociedade brasileira, conforme apontam inúmeros autores (RodRIGUES, 1988; MARICATO, 1996; 2000; FERNANDES, 2007), o que dificulta, por conseguinte, qualquer tipo de ação política que passe pela contestação do direito de propriedade. Este, sem dúvida, é um dos principais dilemas e dificuldades do movimento de moradia, tanto para conseguir mobilizar uma base social mais ampla como para se constituir enquanto um ator legítimo no campo da opinião pública.

Vale lembrar ainda que este questionário foi aplicado a pessoas que, em sua ampla maioria, representam posições de liderança intermediária no âmbito da UMM. Acreditamos que, na base do movimento, a proporção de indivíduos que se apegue à ideia de defesa da propriedade privada para 
contestar a legitimidade das ocupações seja significativamente maior, visto que, como já insinuamos, tal argumento tem um forte apelo em amplas parcelas da sociedade brasileira. É interessante notar que o Brasil possui hoje uma das legislações mais avançadas do mundo em matéria de política urbana, sintetizada na Lei Federal n 10.257/2001 (Estatuto da Cidade), cuja base jurídica reside justamente no princípio da função social da propriedade (FERNANDES, 2007; MARICATO, 2010), ou seja, na regulação pública do uso da propriedade. Essa legislação possibilita ao movimento de moradia embasar-se em princípios jurídico-legais para legitimar suas reivindicações e a forma como estas são encaminhadas, incluindo as ocupações de imóveis que em princípio estejam em desacordo com a Lei. Isto significa que a própria legislação fornece os parâmetros necessários para a construção de um discurso nessa direção, mas, como vimos, não existe uma relação automática entre o ordenamento jurídico-legal e a construção discursiva da ação coletiva.

Vemos, portanto, como a defesa da propriedade privada coexiste com a defesa da proeminência do direito de moradia em relação ao direito à propriedade. Essas questões evidenciam alguns dos dilemas que o movimento de moradia enfrenta no que diz respeito à definição de suas estratégias de luta. A ocupação, que é indiscutivelmente uma das principais formas de ação mobilizadas pelos atores em questão, não encontra um consenso em termos de sua legitimidade nem mesmo entre indivíduos que ocupam posição de relativa importância na rede movimentalista. Lembramos aqui Polletta, que, atenta à ambiguidade ou à polissemia, como uma das características presentes nos movimentos sociais, afirma que "É precisamente a ambiguidade sobre as causas da ação coletiva que seduz potenciais ativistas" (POLLETTA, 1998, p.139, livre tradução; grifo no original). O poder da polissemia na mobilização reside precisamente no fato de que "...sentidos subversivos devem coexistir com sentidos dominantes" (POLlETTA, 1998, p.142, livre tradução). Na próxima seção, exploramos uma questão que gera muito menos controvérsia: a participação nos espaços institucionais.

\section{Participação Institucional: a importância do $\mathrm{CMH}$ para o movimento}

Os movimentos sociais brasileiros têm atuado em cenários caracterizados por uma ampliação significativa das oportunidades para a participação institucional. Desde a última década, a sociedade civil tem sido chamada a participar de um conjunto de novos espaços de deliberação e gestão das políticas, em diversas áreas e a partir de diferentes modelos institucionais, como os conselhos, orçamentos participativos, fóruns, comitês de bacia, etc. Essas experiências são muito diferenciadas em relação aos modelos institucionais e aos projetos políticos que thes dão vida e aos resultados que alcançam (Cf. Dagnino, 2002; Dagnino, Olvera, Panfichi, 2006; Dagnino e Tatagiba, 2007).

Tanto dentro quanto fora da academia estão sendo realizados balanços avaliando até onde se avançou a partir dessa aposta na "luta por dentro do Estado". O diagnóstico mais geral chama a atenção para $\circ$ fato de que "...os resultados das experiências concretas estão muito aquém das expectativas lançadas sobre elas. Uma das principais críticas está na dificuldade desses processos resultarem em efetiva melhoria das condições de vida da população, principalmente dos grupos mais pobres" (TATAGIBA, 2009). Essa avaliação, somada às dificuldades de conciliar trabalhos junto à base com o investimento no 
TATAGIBA, L.; PATERNIANI, S. Z.; TRINDADE, T. A. Ocupar, reivindicar, participar...

aprendizado técnico requerido para participar nesses espaços, tem levado alguns atores a repensar a prioridade dada à dimensão institucional como forma de luta política. Ainda de acordo com Tatagiba, embora esse debate seja importante por colocar em pauta a questão das estratégias de atuação dos movimentos, ele acabou preso na armadilha de contrapor, de forma essencialista e polarizada, participação institucional e ação mobilizatória, favorecendo um discurso pendular que ora aposta na participação institucional, ora sugere o abandono de qualquer tipo de envolvimento com dinâmicas participativas institucionalizadas em favor da ação direta. Com isso, o que se perde é a possibilidade de problematizar os desafios concretos que os movimentos encontram para escolher/combinar estratégias em um contexto altamente complexo, que Ihes impõem importantes vetos à coordenação de suas ações (TATAGIBA, 2009). No caso do movimento de moradia, é importante levar em conta que a participação institucional faz parte da tradição de relações entre movimento e Estado, dividindo espaço com ações diretas e com maior potencial disruptivo como as ocupações. Como afirmam Abers, Serafim e Tatagiba, referindo-se à experiência de articulação entre o campo da reforma urbana na esfera federal,

\begin{abstract}
"[no caso da] política urbana, a partir de uma significativa experiência de articulação entre movimentos sociais e atores político-institucionais que remonta às lutas em torno da Constituinte, o lobby parlamentar e a participação institucional (via conselhos e conferências) acabaram se constituindo como elementos centrais do repertório dos movimentos em torno da reforma urbana, indicando uma disposição no sentido da institucionalização dos conflitos deste setor. Estas modalidades combinaram-se com estratégias de protesto tradicionais no setor, como as ocupações e as marchas" (ABERS, Serafim E TATAGIBA, 2011, p.05).
\end{abstract}

Em São Paulo, um importante espaço para atuação institucional do movimento de moradia é o Conselho Municipal de Habitação (CMH). O CMH foi criado em 2002, na gestão da prefeita Marta Suplicy, do PT, após forte pressão do movimento e seus aliados no campo político institucional. O CMH é uma instância de participação que aciona diferentes modalidades de representação; e é composto por 48 membros titulares e igual número de suplentes. O poder público possui um terço dos assentos. Os outros dois terços são reservados aos conselheiros da sociedade civil, sendo 16 representantes de entidades comunitárias e de organizações populares ligadas à habitação; e 16 representantes de outras entidades da sociedade civil ligadas à questão habitacional, como ONGs, universidades, sindicatos etc. Os representantes do poder público são indicados pelo Poder Executivo; os representantes das entidades da sociedade civil são eleitos por seus respectivos segmentos em fóruns próprios e, finalmente, os representantes das entidades populares ligadas à habitação são escolhidos por meio de eleições nas subprefeituras $^{18}$. As eleições dos representantes populares têm mobilizado não apenas o movimento de

18 A eleição para escolha das organizações populares é territorializada e direta, e o único requisito para participar é possuir o título de eleitor na cidade de São Paulo. Para votar, o eleitor deve comparecer à subprefeitura da região de sua zona eleitoral munido do título de eleitor. A eleição é coordenada pela Secretaria Municipal de Habitação através da Secretaria Executiva do CMH (TATAGIBA e BliKSTAD, 2011). 
OPINIÃO PÚBLICA, Campinas, vol. 18, n², novembro, 2012, p. $399-426$

moradia, mas também partidos e o governo, e têm contado com um crescente comparecimento às urnas dos cidadãos paulistanos: na primeira eleição, realizada em 2003, participaram do pleito mais de 31 mil eleitores, em 2009, foram mais de 47 mil eleitores, e para a próxima eleição (a ser realizada em 2012) mais de 100 mil eleitores estão cadastrados para votar (TATAGIBA e BLIKSTAD, 2011).

Segundo sua lei de criação, $\mathrm{n}^{\circ}$ 13.425, de 02/09/2002, o CMH é um órgão deliberativo, fiscalizador e consultivo, vinculado à Secretaria Municipal de Habitação e Desenvolvimento Urbano, e tem como objetivos básicos o estabelecimento, acompanhamento, controle e avaliação da política municipal de habitação e gestão do Fundo Municipal de Habitação $(F M H)^{19}$. Esse potencial deliberativo faz do Conselho um espaço potencialmente capaz de intervir em interesses econômicos poderosos na cidade, associados ao capital imobiliário e à construção civil. Os principais temas em disputa no $\mathrm{CMH}$ são a produção de moradia para população de baixa renda e o direito das classes populares de morarem no centro, temas centrais na agenda do movimento.

No survey, buscamos aferir o nível de conhecimento dos militantes sobre o $\mathrm{CMH}$ e a avaliação que de fazem sob a chave dos resultados para o movimento (Tabela 9). Um primeiro dado nos surpreendeu: apenas $8,9 \%$ dos entrevistados afirmaram nunca ter ouvido falar do $\mathrm{CMH}$. Buscamos então saber se o entrevistado considerava que o conselho estava sendo importante para a luta o movimento: do total dos que conheciam o Conselho, apenas 4 afirmaram que não e 6 não souberam se posicionar. Portanto, à primeira vista, um quadro que mostra uma expressiva valorização do Conselho, com um nível de divergência muito menor do que a identificada no caso das ocupações: afinal, para $78 \%$ dos entrevistados, o CMH tem sido importante para fazer avançar a luta do movimento.

Tabela 9

Informação e importância do Conselho Municipal de Habitação, segundo os entrevistados

\begin{tabular}{|l|c|c|}
\hline \multicolumn{1}{|c|}{ Respostas } & N & \% \\
\hline Nunca ouviu falar do CMH & 13 & 8,9 \\
\hline $\begin{array}{l}\text { Ouviu falar do CMH e considera que ele tem sido } \\
\text { importante para o movimento }\end{array}$ & 115 & 78,2 \\
\hline $\begin{array}{l}\text { Ouviu falar do CMH e não o considera } \\
\text { importante para o movimento }\end{array}$ & 04 & 2,7 \\
\hline $\begin{array}{l}\text { Ouviu falar do CMH, considera importante, mas } \\
\text { aponta problemas no seu funcionamento }\end{array}$ & 09 & 6,1 \\
\hline Ouviu falar, mas não sabe avaliar & 06 & 4,1 \\
\hline Total & 147 & 100 \\
\hline
\end{tabular}

Contudo, a terceira pergunta do bloco que buscava levar o entrevistado a refletir sobre os motivos da importância do $\mathrm{CMH}$ para o movimento nos conduz a quadro muito mais matizado: dos que conhecem e avaliam positivamente o $\mathrm{CMH}, 9$ afirmam que, embora o $\mathrm{CMH}$ seja importante, ele tem tido

${ }^{19}$ Para uma análise mais detalhada do CMH de São Paulo, remetemos a Tatagiba e Teixeira (2007). 
TATAGIBA, L.; PATERNIANI, S. Z.; TRINDADE, T. A. Ocupar, reivindicar, participar... problemas que limitam sua capacidade de intervir na política. Dentre esses problemas, os entrevistados citaram principalmente a dependência do $\mathrm{CMH}$ em relação à vontade política dos governos. Para os 115 entrevistados que afirmaram a importância do $\mathrm{CMH}$ para o movimento sem qualquer ressalva, os motivos apresentados dividem-se nas seguintes categorias (Tabela 10):

Tabela 10

Motivos da importância do Conselho Municipal de Habitação para o movimento de moradia

\begin{tabular}{|l|c|c|}
\hline \multicolumn{1}{|c|}{ Respostas } & N & \% \\
\hline Porque é um espaço de decisão sobre a política pública habitacional & 23 & 21 \\
\hline Porque todo espaço que se abre é bom e fortalece a luta do movimento & 23 & 21 \\
\hline $\begin{array}{l}\text { Porque é um espaço de representação de interesses e encaminhamento de } \\
\text { demandas }\end{array}$ & 22 & 20 \\
\hline O conselho dá informação e orientação & 15 & 13 \\
\hline Através do CMH se obtêm conquistas & 9 & 7,8 \\
\hline Porque é um espaço que favorece o diálogo e o debate & 8 & 7 \\
\hline Não sabe por que é importante & 6 & 5,2 \\
\hline Outros & 6 & 5,2 \\
\hline Total & 112 & 100,0 \\
\hline Fonte: Pesquisa Movimento de Moradia, 2009.
\end{tabular}

O primeiro motivo ressalta a importância da função deliberativa do Conselho em relação à produção da política habitacional. Como dissemos, o Decreto de criação do Conselho o define como um órgão deliberativo, ou seja, com poder para decidir sobre a política pública. Sabemos que, na prática, a força deliberativa do Conselho é dependente da correlação de forças que se estabelece dentro e fora dele. Contudo, o fato de ser um espaço legalmente investido de poder de decisão é algo que foi muito valorizado no processo de criação dessas instâncias e que permanece um eixo central, como evidenciado em frases como: "é uma forma institucional de participação com poder de voto e decisão" (quest. 147); "é um lugar onde se decidem projetos" (quest.66); "através dele é que se consegue deliberar no âmbito da moradia... Sem $\mathrm{CMH}$ não se conseguia nada" (quest. 59), "o conselho ajuda a definir o orçamento (quest.77). Um outro conjunto de motivos remete ao papel de representação do Conselho. A representação assume, contudo, vários sentidos. Um primeiro é a ideia de que por meio do conselho se chega aos governantes. $\mathrm{O} \mathrm{CMH}$ aparece como uma forma de estar perto do poder, encaminhar demandas e afirmar interesses de um conjunto de atores que se afirma como movimento, como organizações do movimento, como população sem moradia, ou como pobres num registro mais amplo. O Conselho aparece aí como importante espaço de mediação para chegar ao Estado, exercendo, nesse sentido, a função de representação. Ele em si representa um coletivo ou é um espaço para representação de um coletivo: "sem o CMH as pessoas não têm o poder de chegar até o governo e se representar" [quest.10]. Uma outra dimensão associada à ideia de representação remete à possibilidade das organizações do 
OPINIÃO PÚBLICA, Campinas, vol. 18, no 2, novembro, 2012, p. $399-426$

movimento, principalmente aquele com atuação mais local, participarem do jogo da política. Nesse caso, o $\mathrm{CMH}$ faz avançar a luta do movimento, porque permite à organização se fazer representar no jogo do poder, "uma das nossas coordenadoras [coordenadora de uma organização do movimento situada em Brasilândia] é conselheira. E ela está bem próxima das informações, e lá ela fala por nós" [quest. 74]; "o $\mathrm{CMH}$ é importante porque leva as necessidades da nossa associação para um coletivo maior" [quest.02].

$\mathrm{O}$ acesso à informação foi apontado por $13 \%$ dos entrevistados como a principal contribuição do Conselho ao movimento, confirmando o que outros estudos têm apontado (TATAGIBA e TEIXEIRA, 2007): estar no Conselho é obter informação em "primeira mão". Tatagiba e Blikstad (2010) chamam a atenção para as duas dimensões implicadas nessa questão: "a informação é importante para o movimento de moradia, mas o é também para as organizações do movimento que assumem assento como representantes. Estar no Conselho é saber, antes mesmo da divulgação oficial, os editais de financiamento que serão abertos, os prédios ou terrenos que serão disponibilizados para HIS (Habitação de Interesse Social), as oportunidades de financiamento, etc.", e isso permite tanto ao movimento como um todo construir suas estratégias, quanto às organizações chegar na frente das outras do seu campo na competição pelos recursos escassos da política habitacional. A questão da informação veio junto com a questão da formação: estar no Conselho é bom porque é possível aprender como funciona a máquina do Estado. A importância estratégica do Conselho para a conquista da moradia foi ressaltada por 7,8 \% dos entrevistados. É o mesmo percentual dos que entendem que o $\mathrm{CMH}$ é importante para o movimento porque confere um lugar para a realização de debates de discussão. Aqui, mais do que a relação com o governo, a ênfase está na possibilidade de diálogo entre os próprios movimentos.

Mas, voltando ao topo da Tabela 10, chamam atenção os $20 \%$ que afirmaram que o $\mathrm{CMH}$ contribui para o movimento, porque "todo espaço que se abre é bom". As respostas nessa categoria não identificaram nenhuma característica do Conselho que o tornasse estratégico para o movimento. São respostas que se mantêm em um nível alto de generalidade e que, no limite, demonstram um desconhecimento do conselho, ou pelo menos um conhecimento bastante superficial. Não é possível depreender delas nenhuma valorização da participação institucional per se. Vejamos alguns exemplos: "é mais um mecanismo de atuação do movimento" [quest.65]; "porque fortalece" [quest.28]; "ajuda na luta" [quest.75]; "tudo o que for para ajudar tá bom" [quest.108]; "só de falar de habitação tá bom" [quest. 89]. Quando comparamos o conjunto de respostas que remete ao potencial deliberativo do conselho (que também foi mencionado por 20\%) o contraste fica evidente: de um lado, militantes que mobilizam os termos e expectativas que circundam as experiências de democracia participativa; de outro, a positividade do Conselho está em ser mais um lugar, mais uma porta aberta para o movimento, do qual não se sabe bem ao certo o que esperar. Podemos assumir que esse reconhecimento genérico da importância do $\mathrm{CMH}$ pode significar um baixo nível de envolvimento do movimento com o Conselho, uma vez que, diferente do mutirão e das ocupações, ele não exige mobilização, a qual fica, no geral, restrita às suas principais lideranças. E também pode significar uma baixa adesão à própria ideia da participação institucional como estratégia para alcançar as demandas do movimento. De qualquer forma, nossos dados não nos permitem avançar em nenhuma das duas direções. 
TATAGIBA, L.; PATERNIANI, S. Z.; TRINDADE, T. A. Ocupar, reivindicar, participar... Direito à cidade: a disputa pelo centro como estratégia de ação

O conceito de direito à cidade aparece primeiramente na obra de Lefebvre (2008 [1968]), filósofo e sociólogo francês de orientação marxista. Para este autor, a ideia de direito à cidade surge como uma utopia, uma plataforma política que deveria orientar a luta das classes trabalhadoras urbanas contra a lógica capitalista de produção do espaço, responsável por organizar a cidade segundo uma perspectiva racionalista-pragmática que, além de escamotear os conflitos de classe ("empurrando" os pobres para a periferia), mercantiliza o solo urbano e transforma a cidade numa engrenagem funcional à expansão do capital. Nesse sentido, o direito à cidade aparece como o direito de (re)apropriação da centralidade urbana pelas classes populares. A partir dessa definição, o debate acadêmico no Brasil e mesmo na América Latina (FERNANDES, 2007; MARICATO, 1996; 2000) associou a ideia de direito à cidade à possibilidade de usufruir de forma plena e satisfatória das oportunidades, vantagens e serviços sociais oferecidos pela cidade. 0 direito à cidade, portanto, não é equivalente ao direito à moradia; o primeiro é muito mais amplo e complexo, pois considera a localização do indivíduo no sistema urbano em seu conjunto e a possibilidade de acesso às melhores localizações da cidade.

Como os centros históricos das grandes cidades são, no geral, mais bem estruturados do que as outras localizações, a noção de direito à cidade aparece muitas vezes associada ao direito de morar no centro. $\mathrm{O}$ direito à cidade seria, então, o direito ao centro, uma vez que morar na periferia distante e longínqua dos empregos e dos serviços sociais mais qualificados é bastante desvantajoso para a ampla maioria dos trabalhadores mais pobres, que dependem essencialmente dos serviços de transporte coletivo para acessar as regiões mais urbanizadas. Ademais, há uma questão aqui que nos parece fundamental: como demonstrado por Kowarick (2009), o centro da cidade tem um valor e uma importância simbólica muito grande no imaginário das classes populares, pois "é no centro que tudo acontece". Acreditamos que esse valor simbólico estimule a associação entre a cidade e o centro; o centro é a própria cidade, pois é o local dos acontecimentos mais importantes, lugar do encontro e do convívio social, onde a diversidade, portanto, se evidencia. Daí o sentido do termo "direito à cidade". É no centro que as classes populares se sentem mais integradas à cidade e à sociedade, ainda que esta integração seja também muito parcial em razão de múltiplos obstáculos (culturais, políticos e econômicos).

Esse é um debate intenso e atual dentro do campo maior da questão habitacional na cidade de São Paulo: a questão dos usos, das lutas e dos projetos para o centro da cidade, como indicamos na introdução. 0 processo de gentrification (ou "enobrecimento") tem sido uma política generalizada nas áreas centrais de grandes cidades brasileiras, e ancora-se em três princípios: patrimonialização cultural, requalificação dos usos da cidade e melhorias na infraestrutura urbana (LEITE, 2007, p. 20) - com vistas a transformar o patrimônio cultural dos "centros históricos" em mercadoria cultural e bem de consumo turístico. De acordo com vários manifestos divulgados recentemente pelos movimentos populares, os preparativos para a realização dos megaeventos que estão programados para os próximos anos no Brasil, a saber, a Copa do Mundo em 2014 e as Olimpíadas de Verão, em 2016, estariam contribuindo para acelerar um projeto de "higienização social" do centro que vem sendo colocado em prática pela 
OPINIÃO PÚBLICA, Campinas, vol. 18, n², novembro, 2012, p. $399-426$

atual administração em São Paulo e em diversas outras capitais brasileiras. É contra essa política que o movimento de moradia levanta a bandeira do "direito de morar no centro", chamando a atenção para a natureza essencialmente política dos processos de ocupação dos espaços da cidade, como explica Kowarick:

\begin{abstract}
"De um lado a ênfase na limpeza, na ordem, no controle, no esquadrinhamento, disiciplinarização e policiamento; de outro a priorização da função social da propriedade e a ocupação de edifícios que se encontram vazios por parte daqueles que querem exercer o direito de viver nas áreas centrais. Neste sentido, a maneira de ocupar os espaços da Cidade é essencialmente política em dois sentidos: na acepção de que deve ser objeto primordial das políticas públicas (policies) e, sobretudo, de que nela se estruturam interesses diversos e, por vezes, antagônicos, que procuram mobilizar forças para levar adiante suas reivindicações (politics)" (KoWARICK, 2009, p. 154).
\end{abstract}

Buscamos saber até que ponto há adesão dos militantes do movimento a essa bandeira, perguntando aos entrevistados: "Você acha importante a luta pela moradia no centro?" Oitenta e um por cento responderam que sim. Na sequência, buscamos saber os motivos, apresentados na Tabela 11:

Tabela 11

Motivos da importância da luta por moradia no centro de São Paulo

\begin{tabular}{|l|l|l|}
\hline \multicolumn{1}{|c|}{ Respostas } & N & $\%$ \\
\hline No centro há infraestrutura e fica próximo de tudo & 27 & 18,4 \\
\hline Todos têm o direito de morar no centro & 24 & 16,3 \\
\hline Existem muitos imóveis ociosos que poderiam ser ocupados com HIS & 23 & 15,6 \\
\hline $\begin{array}{l}\text { O que importa é conseguir a moradia, tanto faz se no centro ou na } \\
\text { periferia }\end{array}$ & 21 & 14,3 \\
\hline $\begin{array}{l}\text { Há pessoas que já moram no centro precariamente e devem ter } \\
\text { melhores condições de moradia }\end{array}$ & 19 & 12,9 \\
\hline Centro com moradia resulta em benefícios para a cidade & 10 & 6,8 \\
\hline Outros & 12 & 8,2 \\
\hline NS/NR & 11 & 7,5 \\
\hline Total & 147 & 100,0 \\
\hline Fonte: Pesquisa Movimento de Moradia, 2009. & & \multicolumn{2}{|c|}{10} \\
\hline
\end{tabular}

O maior percentual $(18,4 \%)$ se valeu do argumento da infraestrutura que o centro apresenta, bem como de sua proximidade a serviços e locais de trabalho; outros $16,3 \%$ referiram-se ao princípio da universalidade de direitos e, especificamente, do direito à cidade: todos teriam o direito a morar no centro.

A referência à disputa entre o projeto posto em prática pelo poder público e o encampado pelos movimentos sociais é pano de fundo da argumentação de 15,6\% dos entrevistados. Estes afirmam 
TATAGIBA, L.; PATERNIANI, S. Z.; TRINDADE, T. A. Ocupar, reivindicar, participar...

existirem muitos imóveis ociosos no centro, os quais poderiam ser ocupados por habitação de interesse social. Opinião reforçada pelos números: dados preliminares do Censo de 2010 indicam que existem hoje na cidade de São Paulo 290 mil imóveis vazios ${ }^{20}$, como dissemos anteriormente. O mesmo projeto parece estar por trás dos que chamam atenção ao fato de já existirem muitos moradores no centro, em condições precárias de habitação (em cortiços, em situação de rua, com aluguéis abusivos etc.); deve-se manter sua permanência no centro, e garantir-Ihes moradia digna (12,9\%). Finalmente, há o argumento de que ocupar o centro com moradia resulta em benefícios para a cidade $(6,8 \%)$, porque a) diminui a criminalidade da região e b) não degrada o meio-ambiente como as moradias em áreas de risco, próximas a regiões de reserva ambiental. Se considerarmos apenas os três primeiros itens da Tabela 11, vemos que um alto percentual de militantes, cerca de $50 \%$ do total, fez referência aos principais eixos discursivos associados ao direito à cidade. Vale a pena citar algumas respostas que se enquadram naquelas categorias: "É onde está consolidada a urbanização. O que não faz sentido é morar na periferia" [quest. 66]; "moradia longe é transtorno com transporte" [quest. 51]; "há uma política higienista no centro, e os prédios vazios precisam exercer sua função social" [quest. 112]; "há muito prédio abandonado e muita gente precisando de moradia" [quest. 123]; "precisamos ter igualdade, não é porque é pobre que precisa morar longe do centro" [quest. 142]; "a cidade é de todos os cidadãos e eles não podem ser excluídos" [quest. 102]. Foram poucos os entrevistados que afirmaram que a luta pelo centro é importante, mas que não souberam argumentar a razão disso. Como podemos ver ainda na Tabela11, apenas 11 entrevistados (7,5\%) não souberam ou não responderam a pergunta.

Isso talvez reforce a tese que já pontuamos no início desta seção, o centro tem um valor simbólico muito relevante no imaginário das classes populares, e por isso, talvez, os militantes do movimento tenham maior facilidade em expor seus argumentos e posições a respeito deste assunto do que em relação à participação em canais institucionalizados. Para além das opiniões dos entrevistados, deve-se fazer mais uma consideração sobre a importância da luta pela moradia no centro da cidade: a minimização dos efeitos negativos decorrentes da segregação socioespacial, processo que vem se acirrando nos últimos anos em razão da proliferação dos loteamentos fechados nas grandes cidades brasileiras (CALDEIRA, 1997; SOUZA, 2000; KOWARICK, 2009). Com efeito, uma política que valorize a produção da habitação popular no centro da cidade - na contramão, portanto, dos projetos higienistas colocados em práticas por diversas administrações municipais atualmente - terá como um de seus principais efeitos a produção de uma cidade mais democrática do ponto de vista do acesso aos espaços públicos mais qualificados, contribuindo ainda de forma relevante para a heterogeneização da paisagem sociocultural que se produz a partir das (conflituosas) relações cotidianas entre as diferentes classes e grupos sociais.

Buscando explorar ainda mais a relação do movimento com a cidade, perguntamos qual seria a principal contribuição do movimento (Tabela 12):

\footnotetext{
${ }^{20}$ Conforme <http://www.estadao.com.br/estadaodehoje/20101207/not_imp650404,0.php>.
} 
OPINIÃO PÚBLICA, Campinas, vol. 18, n², novembro, 2012, p. $399-426$

Tabela 12

Principal contribuição do movimento para São Paulo

\begin{tabular}{|l|c|c|}
\hline \multicolumn{1}{|c|}{ Respostas } & N & \% \\
\hline Conquistas do movimento diminuem as habitações precárias & 30 & 20,4 \\
\hline Coloca na agenda pública a questão da moradia & 30 & 20,4 \\
\hline Conhecimento dos direitos, construção da cidadania e & 27 & 18,4 \\
\hline Aumento da participação e da luta por dentro do Estado & 14 & 9,5 \\
\hline Melhoria das condições de vida (genérico) & 9 & 6,1 \\
\hline Traz pouca ou nenhuma contribuição & 7 & 4,8 \\
\hline Outros & 11 & 7,5 \\
\hline NS/NR & 19 & 12,9 \\
\hline Total & 147 & 100,0 \\
\hline
\end{tabular}

Fonte: Pesquisa Movimento de Moradia, 2009

As respostas mais frequentes apontam para mudanças no plano do discurso e da prática, com igual força. No primeiro caso, os entrevistados referem-se à publicização, ao debate e à conscientização, bem como à inserção na agenda pública da questão da moradia, alterando os marcos discursivos nos quais a questão habitacional fora tradicionalmente abordada. $O$ segundo conjunto de argumentos trouxe à tona as mudanças concretas realizadas na cidade de São Paulo: diminuição das habitações precárias como as favelas, os cortiços, as moradias em áreas de risco, os moradores de rua, e consequente melhoria da cidade - mais limpa, com espaço urbano mais bem organizado. Parte dos que se enveredaram nesse tipo de argumento focaram-se na importância que as lutas do movimento têm na revitalização do centro da cidade e na promoção da Reforma Urbana, com respaldo no Estatuto da Cidade. Reconheceram também como importante a atuação através do Plano Diretor. Outro tipo de argumento forte apontou para a formação política dos militantes, como consciência política crítica, conhecimento de direitos, importância da organização popular e da articulação das lutas. Sete entrevistados (4,8\%), contudo, afirmaram que o movimento de moradia não trouxe nenhuma mudança efetiva nem impacto sobre a cidade ou sobre a vida dos cidadãos: "há muita coisa no papel e pouca ação".

\section{Notas finais}

Este artigo buscou apresentar a heterogeneidade das construções discursivas em torno de três eixos - a ocupação como instrumento político, a participação institucional e a luta pelo direito à cidade que identificamos como fundamentos da construção de uma coletividade do movimento de moradia de São Paulo. Com base em dados de um survey aplicado no $11^{\circ}$ Encontro de Moradia Popular, organizado pela União dos Movimentos de Moradia (UMM), em 2009, na cidade de São Paulo, apresentamos algumas características sócio-políticas dos militantes. Notamos predominância da participação de pessoas adultas, entre 40 e 59 anos, católicas e com vínculos partidários expressivos, principalmente com o Partido dos Trabalhadores. Destaca-se a forte participação das mulheres no movimento. Esse 
TATAGIBA, L.; PATERNIANI, S. Z.; TRINDADE, T. A. Ocupar, reivindicar, participar...

retrato talvez não divirja muito do que poderia ser dito em décadas anteriores, embora tenhamos sinais de mudança: a participação dos evangélicos e a presença - ainda tímida, mas importante - de militantes filiados ou simpatizantes do PSDB.

Consideramos o movimento de moradia como um ator complexo, plural e heterogêneo, e, por isso, o retrato aqui apresentado é parcial, tanto no que se refere aos diversos grupos que compõem o movimento, como ao caráter dinâmico da conformação das redes e dos trânsitos dos atores entre elas que configuram a trama movimentalista. Conscientes desses limites, cremos, contudo, que os resultados são relevantes para reforçar e reconfigurar problemas de pesquisa sobre o tema da ação coletiva e participação política. No que se refere à participação no movimento, conclui-se que o movimento manteve ao longo dos anos 2000 uma importante capacidade de recrutamento de novos militantes, ao mesmo tempo em que continuou contando com uma base de militantes experientes, vinte por cento deles engajados há mais de 20 anos.

Os dados mostram uma considerável identificação dos entrevistados com os valores que distinguem a rede movimentalista, os quais podem ser sumarizados na ideia de moradia digna. 0 que os entrevistados nos dizem, quando olhamos de forma transversal para os três eixos, é que a conquista da casa não encerra o sentido da demanda. Há algo mais em jogo que vemos claramente refletido quando questionamos sobre os sentidos da participação, e ouvimos dos entrevistados a referência à noção de dignidade como algo que qualifica e amplia a luta - ampliando, inclusive, o sentido de 'moradia'. Kowarick já havia chamado a atenção para a importância desse termo associado às tentativas de subverter a humilhação que acompanha a situação de vulnerabilidade (KOWARICK, 2009).

Por outro lado, os dados também refletem que há níveis diferenciados de referência aos valores em torno dos quais se estruturam e legitimam as ações do movimento, os quais evidenciam a diversidade do movimento e o desafio da construção simbólica em contextos em constante mudança. Como vimos, apenas $57 \%$ dos entrevistados defendem as ocupações. Entre as avaliações negativas, dois argumentos se destacam: sua natureza intrinsecamente violenta (34\%) e o fato de desrespeitarem a propriedade privada (25\%). No caso da participação, se no começo de nossa análise os dados nos apresentavam um alto índice de adesão dos militantes ao $\mathrm{CMH}$, com 78\% dos entrevistados afirmando que o $\mathrm{CMH}$ era importante para fazer avançar a luta do movimento; quando realizamos uma análise mais fina, vemos que, do total de 147 entrevistados, apenas 56\% demonstraram conhecimento mais efetivo sobre o Conselho e uma avaliação que apontava para seu papel como estratégia de ação do movimento. De fato, o que nos parece mais relevante aqui não é a participação em si, mas a forma, o alcance e a qualidade desta participação (DAGNINO, 2005). Afinal, como sabemos, por detrás de uma aparente sintonia discursiva, há uma profunda disputa política a respeito do significado efetivo da participação social nos espaços institucionais. No que se refere à luta pelo direito à cidade, o alto nível de adesão foi também acompanhado por uma capacidade dos entrevistados em apontar os ganhos individuais e coletivos com essa estratégia, o que parece indicar um maior alinhamento desse discurso com as experiências cotidianas dos militantes. 
OPINIÃO PÚBLICA, Campinas, vol. 18, n², novembro, 2012, p. $399-426$

\section{Referências Bibliográficas}

ABers, R.; SerafiM, L. e TATAgiBA, L. A participação na era Lula: repertórios de interação em um Estado heterogêneo. Anais do $35^{\circ}$. Encontroo Anual da Anpocs, Caxambu, 2011.

AlmeidA, R. "Religião na Metrópole Paulista”. Revista Brasileira de Ciências Sociais. São Paulo, vol. 19, n’ 56, p. 15-27, 2004.

Avritzer, L. A participação em São Paulo. São Paulo: Editora Unesp, 2004.

BenOIT, H. "A luta popular pela moradia - entrevista com Luís Gonzaga da Silva (Gegê)". Crítica Marxista, n¹0, p.157-172, out. 2000.

CALDEIRA, T.P. "Enclaves fortificados: a nova forma de segregação urbana". Revista Novos Estudos, vol.47, SP, CEBRAP, 1997.

Cardoso, R. Movimentos sociais: balanço crítico. In: SoRJ, B. AlmeidA, M. H. T. (orgs.). Sociedade e política no Brasil pós. 64. São Paulo: Brasiliense, 1983.

fev. 1987.

. "Movimentos sociais na América Latina". Revista Brasileira de Ciências Sociais, São Paulo, vol. 1, n 3,

Cavalcantı, G.C.V. Uma concessão ao passado: trajetórias da União dos Movimentos de Moradia de São Paulo. São Paulo. 148 pp. Dissertação de Mestrado em Sociologia. USP, 2006.

CYMBALYSTA, R.; SANTORO, P.F. Habitação - avaliação da política municipal 2005-2006. In: CYMBALYSTA, R. et al. (orgs.) Habitação e controle social da política pública. São Paulo: Observatório dos Direitos do Cidadão/Pólis/PUC.SP, 2007.

CRESS, D. \& SNOW, D. "The outcomes of homeless mobilization the influence of organization, disruption, political mediation and froming". The American Journal of Sociology, vol.105, n4, 2000.

DAGNINO, E. Sociedade civil, espaços públicos e a construção democrática no Brasil: limites e possibilidades. In: DAGNINO, E. (org.). Sociedade civil e espaços públicos no Brasil. São Paulo: Paz e Terra, 2002. Políticas culturais, democracia e o projeto neoliberal. Revista Rio de Janeiro, n 15, 2005.

Dagnino, E.; Olvera, A. e Panfichi, A. (orgs.). A Disputa pela construção democrática na América Latina. São Paulo: Paz e Terra, 2006.

Dagnino, E.; TAtAGIBA, L. Democracia, sociedade civil e participação. Editora Argos, Unichapecó, 2007.

DIANI, M. Networks and social movements: a research programme. In: DIANI, M.; MCADAM, D. (eds.). Social movements and networks. Relational approaches to collective action. Oxford: Oxford University Press, 2003.

DIANI, M.; MCADAm, D. (eds.). Social movements and networks. Relational approaches to collective action. Oxford: Oxford University Press, 2003.

DILLEY, R. The problem of context - methodology and history in anthropology. Oxford: Berghahn Books, 1999.

Doımo, A. M. A vez e a voz do popular. movimentos sociais e participação política no Brasil pós-70. Rio de Janeiro: Relume. Dumará, 1995.

Fernandes, E. "Constructing the 'Right to the City' in Brazil”. Social \& Legal Studies, vol. 16, n², p. 201-219, 2007.

FóRUm Centro Vivo. Violações dos direitos humanos no centro de São Paulo: propostas e reivindicações para políticas públicas. Dossiê de denúncia. São Paulo: Fórum Centro Vivo (mimeo), 2006. Disponível em:

<http://dossie.centrovivo.org/Main/HomePage>. Acesso em: 01 mar. 2011.

Genevols, M.L.B.P.; CostA, O. V. "Carência habitacional e déficit de moradias: questões metodológicas". São Paulo em Perspectiva, vol. 15, 2001.

GIUGNI, M. "What it worth the effort? The outcomes and consequences of social movements". Annual Review of Sociology, p. 371.393, vol. 24, 1998.

GoHn, M. Movimentos sociais e luta pela moradia. São Paulo: Ed. Loyola, 1991. 
TATAGIBA, L.; PATERNIANI, S. Z.; TRINDADE, T. A. Ocupar, reivindicar, participar...

KASSAB, G. "Os limites necessários". O Estado de São Paulo, São Paulo, Espaço aberto, p. 2, 9 nov. 2011.

KowARICK, L. (org.). As lutas sociais e a cidade: São Paulo passado e presente. Rio de janeiro: Paz e Terra, 1988.

Viver em risco. São Paulo: Editora 34, 2009.

LefEBVRE, H. O direito à cidade. São Paulo: Centauro, 2008 [1968].

LEITE, R. Contra-usos da cidade. Editora da Unicamp/Editora UFS, 2007.

MARICATO, E. Metrópole na periferia do capitalismo: ilegalidade, desigualdade e violência. São Paulo: Hucitec, 1996.

. As ideias fora do lugar e o lugar fora das ideias. In: Arantes, O.; Vainer, C.; Maricato, E. (orgs.). A cidade do pensamento único: desmanchando consensos. Petrópolis: Vozes, 2000.

. O Estatuto da cidade periférica. In: Aliança de Cidades e Ministério das Cidades (orgs.) O Estatuto da Cidade comentado, 2010.

MARQues, E. e ToRres, H. "Tamanho populacional das favelas paulistanas. Ou os grandes números e a falência do debate sobre a metrópole". In: Encontro da Associação Brasileira de Estudos Populacionais - Caxambu, MG, 2002.

MiAguSKo, E. Movimentos de moradia e sem-teto: experiências no contexto do desmanche. Tese de doutorado. Faculdade de Filosofia, Letras e Ciências Humanas da Universidade de São Paulo. São Paulo, USP, 2008.

Meluccl, A. Challenging Codes: Collective Action in the Information Age. Cambridge University Press: Cambridge, 1996. A invenção do presente. Movimentos sociais nas sociedades complexas. Rio de Janeiro: Vozes, 2001.

MISCHE, A. Partisan Publics. New Jersey: Princeton University Press, 2008.

NeUHold, R. Os movimentos de moradia e sem-teto e as ocupações de imóveis ociosos: a luta por políticas públicas habitacionais na área central da cidade de São Paulo. Dissertação de mestrado. Faculdade de Filosofia, Letras e Ciências Humanas da Universidade de São Paulo. São Paulo, USP, 2009.

PATERniani, S. Cultura e política em movimentos de moradia na cidade de São Paulo II. Relatório final de atividades. Programa Institucional de Bolsas de Iniciação Científica PIBIC/CNPq. Campinas: Unicamp, quota ago/2009-jul/2010, 2010.

PollettA, F. "It was like a fever..." - Narrative and identity in social protest. Social Problems, vol. 45, n², May 1998.

PoRTA, D. D. and DIANI, M. Social movements. An introduction. $2^{\mathrm{a}}$ ed. Blacwell Publishing, 2008.

Rodrigues, A. M. Moradia nas cidades brasileiras. São Paulo: Contexto, Edusp, 1988.

RolNik, R. CYMBALISTA, R.; NAKANO, K. Solo urbano e habitação de interesse social: a questão fundiária na política habitacional e urbana do país. 2008. [online] Disponível em:

<http://www.usp.br/srhousing/rr/docs/solo_urbano_e_habitacao_de_interesse_social.pdf>.

Rossetto, R. Fundo Municipal de Habitação. São Paulo, Instituto Pólis / PUC.SP. Observatório dos Direitos do Cidadão: acompanhamento e análise das políticas públicas da cidade de São Paulo, vol. 15, 2003. Disponível em: <http://polis.org.br/obras/arquivo_129.pdf>.

SouZA, M. L. de. O desafio metropolitano: um estudo sobre a problemática sócio-espacial nas metrópoles brasileiras. Rio de Janeiro: Bertrand Brasil, 2000.

TARROW, S. "Struggling to reform: Social movements and policy change during cycles of protest". Center for International Studies, Western Societies Occasional paper no. 15. Ithaca, NY: Cornell University, 1983.

University, USA, 1991.

Struggle, Politics, and Reform: Collective Action, Social Movements, and Cycles of Protest. Cornell Editorial, 1997.

. El poder in movimiento. Los movimientos sociales, la acción colectiva y la política. Madri: Alianza

Poder em Movimento: movimentos sociais e confronto político, Petrópolis: Ed. Vozes, 2009. 
OPINIÃO PÚBLICA, Campinas, vol. 18, n², novembro, 2012, p. $399-426$

Tatagiba, L.; Alvarez, S.; Baiocchi, G.; Lao-Montes, A.; Rubin, N, J. and Thayer, M. (eds.). Interrogating the Civil Society Agenda: Social Movements, Civil Society and Democratic Innovation, 2009.

Relação entre movimentos sociais e instituições políticas na cidade de São Paulo. O caso do movimento de moradia. In: KowARICK, L. e MARQUES, E. (orgs.). São Paulo: olhares cruzados. Sociedade, Política e Cultura, 2010.

TAtAgiba, L.; TelXeiRA, A. C. C. O papel do CMH na política de Habitação em São Paulo. In: TAtAgIBA, L. et al. Habitação: controle social e política pública. Observatório dos Direitos do Cidadão. Acompanhamento e Análise das Políticas Públicas da Cidade de São Paulo, n 31. São Paulo: Instituto Pólis, p. 61·114, 2007.

TATAGIBA, L.; BLIKSTAD, K. A participação do movimento de moradia na eleição de representantes das organizações populares para o Conselho Municipal de Habitação $(\mathrm{CMH})$ da cidade de São Paulo. São Paulo. Paper apresentado no $34^{\circ}$ Encontro Anual da Anpocs, 2010.

TeixeIRA, A. C.C. e TAtagiBA, L. Movimentos sociais e sistema político: os desafios da participação. São Paulo: Polis/PUC. SP, 2005.

TILly, C. Popular Contention in Great Britain, 1758-1834. Cambridge: Harvard University Press, 1995.

Contentious Repertoires in Great Britain, 1758-1834. In: TRAUGOTT, M. Repertoires and cycles of collective action. Durham, NC: Duke University Press, 1995b.

Regimes and Repertoires. Chicago: University of Chicago Press, 2006.

Luciana Tatagiba - lucianatatagiba@uol.com.br

Stella Paterniani · stella.paterniani@gmail.com

Thiago Aparecido Trindade ·thiagoat2005@yahoo.com.br

Submetido à publicação em março de 2011.

Versão final aprovada em dezembro de 2011. 